\title{
Peramalan Luas Panen Padi Indonesia dengan Model ETS (Error, Trend, Seasonal)
}

Kadir

Sub-koordinator Statistik Tanaman Pangan, Badan Pusat Statistik (BPS), kadirsst@gmail.com

Octavia Rizky Prasetyo

Fungsional Statistisi Ahli Pertama, Badan Pusat Statistik (BPS), octavia.rizky@bps.go.id

\begin{abstract}
ABSTRAK, Makalah ini bertujuan untuk mengevaluasi akurasi perkiraan potensi luas panen padi yang dihasilkan melalui metode Kerangka Sampel Area (KSA) dan menyajikan alternatif metode perkiraan luas panen padi dengan mempertimbangkan unsur musimam pada data. Data yang digunakan dalam penelitian ini adalah data realisasi dan potensi luas panen padi hasil Survei KSA periode Januari 2018 sampai dengan Desember 2020. Evaluasi akurasi yang digunakan yaitu nilai Mean Absolute Error (MAE), Root Mean Square Error (RMSE), dan Mean Absolute Percentage Error (MAPE). Metode alternatif peramalan yang digunakan adalah metode ETS. Hasil penelitian menunjukkan perkiraan luas panen padi satu bulan ke depan dengan menggunakan metode KSA memiliki tingkat akurasi yang relatif tinggi, ditunjukkan oleh nilai MAPE yang relatif kecil yakni sebesar 7,52 persen. Sementara itu, ramalan panen menggunakan metode ETS memiliki nilai MAPE, MAE, dan RMSE yang relatif lebih tinggi dibandingkan dengan prediksi panen berdasarkan hasil amatan KSA. Namun, kesalahan peramalan terhadap realisasi luas panen cenderung semakin mengecil seiring dengan penambahan data training. Dengan kata lain, semakin banyak titik data untuk peramalan, semakin baik akurasi hasil peramalan yang dihasilkan oleh metode ETS. Oleh karena itu, model ini dapat dipertimbangkan dalam peramalan luas panen padi dengan menggunakan data hasil Survei KSA ke depannya.
\end{abstract}

Kata Kunci: model peramalan, padi, KSA, akurasi

\section{PENDAHULUAN}

Kebijakan perberasan nasional harus didukung data yang akurat sebagai landasan analisis dan perumusan kebijakan berbasis bukti (evidence based policy). Untuk meningkatkan akurasi data produksi padi nasional, khususnya pengukuran luas panen, sejak 2018, Badan Pusat Statistik (BPS) menerapkan metode Kerangka Sampel Area (KSA) untuk menggantikan metode perkiraan dengan observasi pandangan mata (eye-estimate) yang telah diterapkan selama puluhan tahun sejak tahun 1973. Metode eyeestimate ditengarai menghasilkan pengukuran luas panen padi yang lebih tinggi dari kondisi sebenarnya (overestimate), yakni sekitar 17 persen [1].

Salah satu kelebihan metode KSA adalah mampu menyediakan perkiraan potensi luas panen padi hingga tiga bulan ke depan berdasarkan pengamatan fase tumbuh tanaman padi secara langsung di lapangan. Hal ini sangat penting untuk memenuhi kebutuhan data sebagai dasar formulasi kebijakan yang sifatnya antisipatif dan berorientasi ke depan terkait komoditas beras di Indonesia (early warning system) [2]. Makalah ini mengevaluasi akurasi perkiraan potensi luas panen tersebut melalui ukuran-ukuran statistik yang lazim digunakan dalam peramalan (forecasting). Makalah ini juga menyajikan alternatif peramalan dengan menggunakan metode ETS (error, trend, seasonal), yang pada dasarnya merupakan innovations state space models dari exponential smoothing dengan mengikutkan unsur galat (error), baik aditif (additive) maupun multiplikatif (multiplicative) [3]. Performa model ETS sebagai alternatif metode peramalan luas panen padi ditelaah dengan mengevaluasi akurasi out of sample forecasts data realisasi luas panen hasil KSA periode Januari sampai dengan Desember 2020. Hal ini diharapkan dapat melengkapi pilihan perkiraan luas panen padi hingga tiga bulan ke depan di Indonesia dengan mempertimbangkan unsur musiman (seasonal) pada data.

\section{TINJAUAN PUSTAKA}

\section{Metode Kerangka Sampel Area}

KSA dapat didefinisikan sebagai daftar bidang lahan, seringkali disebut segmen, yang memiliki batas yang jelas dan dapat 
diidentifikasi. Dalam sensus atau survei, segmensegmen tersebut diperlakukan sebagai unit statistik untuk diamati [4]. Sementara itu, KSA juga dapat didefinisikan sebagai desain statistik yang didasarkan pada partisi suatu area menjadi $N$ bagian yang lebih kecil (sub-area) yang disebut unit pengambilan sampel (unit sampling) [5]. Dari unit pengambilan sampel tersebut, $N$ unit dipilih secara acak sebagai area enumerasi dan disebut sampel segmen.

Pengembangan metode KSA di Indonesia untuk pengumpulan statistik pertanian sudah dilakukan pada tahun 1979. Pada saat itu, dengan dana dari pemerintah Amerika Serikat, KSA diperkenalkan untuk pertama kalinya untuk mendapatkan statistik untuk karet, kelapa, dan padi [6]. Penggunaan KSA untuk statistik pertanian telah dilakukan di sejumlah negara, seperti Cina [7]. Pada tahun 2017, Bank Pembangunan Asia (ADB) melalukan uji coba KSA untuk mengestimasi luas panen padi di Laos, Thailand, dan Vietnam [8]. Pengembangan KSA untuk estimasi tanaman padi di Indonesia diawali dengan uji coba di Jawa Barat pada 2015 dan Pulau Jawa pada 2017 sebelum diterapkan di seluruh Indonesia pada 2018. KSA juga telah dikembangkan untuk komoditas jagung sejak 2019 [9].

Penerapan KSA untuk estimasi luas tanaman padi di Indonesia menggunakan data spasial, yakni peta rupa bumi, peta administrasi, peta lahan baku sawah hasil pengolahan citra satelit, dan peta tutupan lahan yang ditumpangsusunkan (overlay), untuk pembangunan kerangka sampel (area frame) melalui proses griding. Unit sampel berupa segmen (area pengamatan) berukuran 9 hektar. Segmen tersebut berupa kotak berukuran $300 \mathrm{~m}$ x 300 m pada peta hasil overlay. Dengan teknik seperti ini, unit sampel lebih mudah didefinisikan dan lokasi segmen dapat diidentifikasi dengan mudah menggunakan teknologi Global Positioning System (GPS) [10]. Pemilihan sampel dilakukan secara acak dengan menerapkan metode systematic aligned sampling with a distance threshold yang diajukan oleh Gallego [11]. Jumlah target sampel segmen pengamatan KSA pada Desember 2020 sebanyak 25.310 segmen. Dalam prakteknya, petugas lapangan melakukan pengamatan fase tumbuh tanaman padi di sembilan titik pengamatan, yang terletak di tengah sub-segmen berukuran satu hektar setiap akhir bulan. Dengan demikian, target pengamatan pada Desember 2020 mencapai 227.790 titik amat.

Fase tumbuh tanaman padi yang diamati terdiri dari fase persiapan lahan, vegetatif awal, vegetatif akhir, generatif, dan panen. Hasil pengamatan kemudian diolah untuk menghasilkan estimasi luas tanaman padi menurut fase tumbuh setiap bulan. Informasi tersebut selanjutnya digunakan untuk memperkirakan potensi luas panen dalam tiga bulan setelah bulan amatan. Potensi luas panen satu bulan ke depan didekati dengan luas fase generatif bulan amatan. Potensi luas panen dua bulan ke depan didekati dengan luas fase vegetatif akhir pada bulan amatan. Adapun perkiraan potensi luas panen tiga bulan ke depan didekati dari informasi luas fase vegetatif awal pada bulan amatan [12].

\section{Model ETS (Error, Trend, Seasonal)}

Model ETS merupakan pengembangan dari model exponential smoothing yang mengikutsertakan unsur stokastik dari data. Dengan demikian, hasil peramalan tidak hanya menyajikan peramalan titik tapi juga selang intervalnya $[13,14,15]$. Karena itu, spesifikai model ETS mengikuti spesifikasi model exponential smoothing dengan tambahan unsur stokastik atau galat (error). Spesifikasi model ETS sangat bergantung pada komponen tren dan musiman pada data. Tabel 1 menyajikan komponen model ETS untuk berbagai kombinasi unsur tren dan musiman yang berbeda. Model ETS telah diterapkan untuk peramalan pada berbagai bidang, seperti peramalan cuaca [16,17], infeksi penyakit [18], dan harga saham [19]. 
Tabel 2.1 Komponen ETS

\begin{tabular}{lccc}
\hline \multirow{2}{*}{ Komponen tren } & \multicolumn{3}{c}{ Komponen musiman } \\
\cline { 2 - 4 } & $\begin{array}{c}\mathrm{N} \\
\text { (none) }\end{array}$ & $\begin{array}{c}\mathrm{A} \\
\text { (Additive) }\end{array}$ & $\begin{array}{c}\mathrm{M} \\
\text { (Multiplicative) }\end{array}$ \\
\hline $\begin{array}{l}\mathrm{N} \\
(\text { None })\end{array}$ & $\mathrm{NN}$ & $\mathrm{NA}$ & $\mathrm{NM}$ \\
$\begin{array}{l}\mathrm{A} \\
(\text { Additive })\end{array}$ & $\mathrm{AN}$ & $\mathrm{AA}$ & $\mathrm{AM}$ \\
$\begin{array}{l}\mathrm{A}_{\mathrm{d}} \\
(\text { Additive }\end{array}$ & $\mathrm{A}_{\mathrm{d}} \mathrm{N}$ & $\mathrm{A}_{\mathrm{d}} \mathrm{A}$ & $\mathrm{A}_{\mathrm{d}} \mathrm{M}$ \\
$\begin{array}{l}\text { Dumped }) \\
\mathrm{M} \\
(\text { Multiplicative })\end{array}$ & $\mathrm{MN}$ & $\mathrm{MA}$ & $\mathrm{MM}$ \\
$\begin{array}{l}\text { M } \\
(\text { Multiplicative }\end{array}$ & $\mathrm{M}_{\mathrm{d}} \mathrm{N}$ & $\mathrm{M}_{\mathrm{d}} \mathrm{A}$ & $\mathrm{M}_{\mathrm{d}} \mathrm{M}$ \\
Dumped $)$ & & & \\
\hline
\end{tabular}

Berdasarkan komponen ETS pada Tabel 2.1 dapat disusun 30 spesifikasi model ETS, masingmasing 15 model untuk model dengan galat aditif dan 15 model untuk model dengan galat multiplikatif. Salah satu spesifikasi model yang memungkinkan diterapkan untuk data hasil KSA adalah ETS (M,N,M) yang mengikutkan unsur galat dan musiman multiplikatif dan tanpa komponen tren. Persamaan untuk model ETS $(\mathrm{M}, \mathrm{N}, \mathrm{M})$ dapat dituliskan sebagai berikut:

$y_{t}=\left(l_{t-1}\right) s_{t-m}\left(1+\varepsilon_{t}\right)$

$l_{t}=\left(l_{t-1}\right)\left(1+\alpha \varepsilon_{t}\right)$

$s_{t}=\left(s_{t-m}\right)\left(1+\gamma \varepsilon_{t}\right)$

di mana $y_{t}$ adalah data runtun waktu, $l_{t}$ adalah komponen level pada waktu $\mathrm{t}, s_{t}$ adalah komponen seasonal pada waktu $\mathrm{t}$, dan $m$ merupakan panjang seasonality.

Penentuan spesifikasi model ETS dapat menggunakan ukuran-ukuran goodness of fit, seperti Akaike's Information Criterion (AIC) dan Bayesian Information Criterion (BIC). Dalam studi ini penentuan spesifikasi model ETS yang digunakan untuk peramalan dilakukan dengan memanfaatkan paket forecast di $\mathrm{R}$ yang didesain secara khusus untuk melakukan peramalan secara otomatis (automatic forecast). Dengan kata lain, pemilihan model terbaik dilakukan secara otomatis dengan menggunakan algoritma yang dibangun oleh Hyndman dan Khandakar [20, 21]. Algoritma tersebut akan memilih model yang paling baik dalam hal goodness of fit. Hasil peramalan dengan model ETS akan dievaluasi dengan menggunakan ukuran-ukuran evaluasi akurasi peramalan yang lazim digunakan, seperti Mean Absolute Error (MAE), Root Mean Square Error (RMSE) dan Mean Absolute Percentage Error (MAPE).

\section{Ukuran Akurasi Peramalan}

Evaluasi perkiraan potensi panen satu, dua, dan tiga bulan ke depan menggunakan beberapa alat evaluasi yang umum digunakan dalam mengevaluasi hasil perkiraan ke depan (forecasting) pada data runtun waktu (time series), yaitu MAE, RMSE dan MAPE. Semakin kecil nilai dari ukuran-ukuran evaluasi ini, semakin dekat nilai prediksi dengan nilai yang sesungguhnya.

MAE merupakan penyimpangan data prediksi dalam unit yang sama pada data, dengan merata-ratakan nilai absolute error seluruh hasil prediksi. Nilai absolut digunakan untuk menghindari nilai penyimpangan positif dan penyimpangan negatif yang dapat saling meniadakan. Rumus MAE yang digunakan dalam penelitian ini adalah sebagai berikut [22]:

$M A E=\frac{1}{n} \sum_{i=1}^{n}\left|e_{i}\right|=\frac{1}{n} \sum_{i=1}^{n}\left|y_{i}-\hat{y}\right|$

dimana:

$\begin{array}{lll}e_{i} & = & \text { error } \\ \text { yi } & = & \text { realisasi panen } \\ \hat{y} & = & \text { potensi panen } \\ \mathrm{n} & = & \text { jumlah sampel }\end{array}$

Sementara itu, RMSE dihitung dari akar kuadrat rata-rata jumlah kuadrat kesalahan perkiraan/peramalan. Secara matematis, RMSE dapat dinyatakan sebagai berikut [22]:

$R M S E=\sqrt{\frac{\sum_{i=1}^{n} e_{i}^{2}}{n}}=\sqrt{\frac{\sum_{i=1}^{n}\left(y_{i}-\hat{y}\right)^{2}}{n}} \ldots \ldots \ldots \ldots$

Selain MAE dan RMSE, kami juga menggunakan alternatif ukuran evaluasi lainnya, yaitu MAPE. MAPE digunakan untuk mengetahui persentase penyimpangan nilai perkiraan/peramalan dengan realisasinya. Secara matematis, MAPE dirumuskan sebagai berikut [22]:

$M A P E=\frac{\sum_{i=1}^{n}\left(\frac{\left|e_{i}\right|}{y_{i}}\right) \times 100}{n}=\frac{\sum_{i=1}^{n}\left(\frac{\left|y_{i}-\hat{y}\right|}{y_{i}}\right) \times 100}{n} \ldots$ 
Kelebihan dari MAPE adalah terbebas dari skala unit dan mudah diinterpretasikan. Menurut Lewis [23], nilai MAPE yang kurang dari 10 persen menunjukkan bahwa hasil prediksi yang dilakukan termasuk dalam kategori sangat akurat (highly accurate). Sementara itu, nilai MAPE yang berada pada rentang 10 sampai dengan 20 persen menunjukkan hasil prediksi yang baik (good forecasting). Nilai MAPE pada rentang antara 20 hingga 50 persen menunjukkan prediksi yang wajar atau beralasan (reasonable forecasting). Jika MAPE melebihi 50 persen maka dapat dikatakan sebagai prediksi yang tidak akurat.

\section{METODOLOGI}

Data yang digunakan dalam penelitian ini adalah data bulanan luas panen dan potensi luas panen padi di Indonesia hasil pengamatan Survei Kerangka Sampel Area (KSA) yang dilakukan oleh BPS sepanjang periode 2018 hingga 2020. Dalam melakukan peramalan, kami menerapkan metode rolling window dengan recursive (expanding) window forecasts [24]. Dengan melakukan ini, performa dari model yang kami ajukan dalam melakukan out-of-sample forecast dapat dievaluasi. Evaluasi dilakukan dengan menggunakan ukuran-ukuran pada persamaan (0.4), (0.5), dan (0.6) dengan membandingkan data hasil forecast dan realisasinya sepanjang periode Januari sampai dengan Desember 2020. Secara teknis, kami membagi data menjadi dua bagian, yakni training set dan test set. Traning set awal mencakup periode Januari 2018 sampai dengan Desember 2019. Metode rolling window (expanding) kemudian dilakukan secara rekursif untuk memperoleh ramalan satu bulan, dua bulan, dan tiga bulan ke depan. Dengan skenario ini, spesifikasi model ETS bisa berubah seiring dengan perubahan cakupan training set untuk mengestimasi model.

\section{Prosedur Analisis}

Data luas panen bulanan hasil KSA dianalisis dengan prosedur sebagai berikut:
1. Mengevaluasi data potensi luas panen satu, dua, dan tiga bulan kedepan yang didekati dengan fase tumbuh tanaman padi (generatif, vegetatif akhir, dan vegetatif awal). Evaluasi dilakukan dengan menghitung ukuran-ukuran akurasi peramalan (MAE, MAPE, dan RMSE).

2. Melakukan peramalan luas panen padi satu, dua, dan tiga bulan ke depan dengan menggunakan model ETS dan mengevaluasi akurasi hasil peramalan dengan menggunakan MAE, MAPE, RMSE dan persentase selisih peramalan. Peramalan dilakukan dengan menerapkan metode rolling window dengan recursive (expanding) window forecasts menggunakan $\mathrm{R}$.

3. Membandingkan akurasi hasil peramalan luas panen dengan metode ETS untuk satu, dua, dan tiga bulan ke depan dengan realisasi panen hasil perhitungan KSA.

\section{PEMBAHASAN}

\section{Akurasi Perkiraan Potensi Panen}

Ringkasan akurasi perkiraan potensi luas panen satu, dua, dan tiga bulan ke depan sepanjang periode Februari 2018 sampai dengan Desember 2020 disajikan pada Tabel 1. Dapat dilihat bahwa perkiraan luas panen padi satu bulan ke depan (one month ahead) dengan menggunakan luas tanaman padi fase generatif pada bulan berjalan cukup akurat. Ini ditunjukkan oleh nilai MAPE yang relatif kecil, yakni sebesar 7,52 persen. Hal ini menunjukkan bahwa prediksi yang dilakukan memiliki akurasi yang sangat baik (higly accurate). Rata-rata absolut perbedaan perkiraan potensi panen satu bulan ke depan dengan realisasi estimasi luas panen hasil pengamatan KSA sebesar 60,76 ribu hektar secara nasional. Sementara itu, perkiraan potensi panen dua dan tiga bulan ke depan dengan menggunakan luas tanaman padi fase vegetatif akhir dan vegetatif awal memiliki nilai MAPE yang relatif besar, yakni masing-masing sebesar 18,94 persen dan 15,04 persen. Nilai MAPE tersebut memperlihatkan bahwa akurasi 
peramalan masih wajar atau dapat diterima. Namun demikian, hal ini memperlihatkan bahwa untuk perkiraan luas panen padi dua dan tiga bulan ke depan diperlukan alternatif model peramalan yang dapat memberikan akurasi yang lebih baik dengan nilai MAPE yang lebih kecil. Rata-rata absolut perbedaan perkiraan potensi panen dua bulan dan tiga bulan ke depan terhadap realisasi luas panen masing-masing sebesar 168,12 ribu hektar dan 121,72 ribu hektar secara nasional. Perbedaan ini akan sangat berarti jika dikonversi ke dalam produksi padi karena secara rata-rata produktivitas padi nasional mencapai sekitar 5 ton per hektar. Informasi yang tersaji pada Tabel 4.1 juga mengindikasikan bahwa penggunaan luas fase vegetatif akhir untuk memperkirakan potensi luas tanaman padi dua bulan ke depan perlu ditelaah lebih dalam.

Tabel 4.1 Akurasi perkiraan potensi panen padi tiga bulan ke depan (3-months ahead)

\begin{tabular}{cccc}
\hline Ukuran & $\begin{array}{c}\text { Potensi 1 } \\
\text { bulan ke } \\
\text { depan }\end{array}$ & $\begin{array}{c}\text { Potensi 2 } \\
\text { bulan ke } \\
\text { depan }\end{array}$ & $\begin{array}{c}\text { Potensi 3 } \\
\text { bulan ke } \\
\text { depan }\end{array}$ \\
\hline MAPE (\%) & 7,52 & 18,94 & 15,04 \\
$\begin{array}{c}\text { MAE (ribu } \\
\text { ha) }\end{array}$ & 60,76 & 168,12 & 121,72 \\
$\begin{array}{c}\text { RMSE } \\
\text { (ribu ha) }\end{array}$ & 81,07 & 197,90 & 144,97 \\
\hline
\end{tabular}

Sumber: Data diolah

\section{Peramalan dengan Model ETS}

Penelitian ini menelaah kemungkinan penggunaan model ETS sebagai alternatif metode peramalan untuk menghasilkan prediksi luas panen yang lebih akurat, khususnya untuk perkiraan luas panen dua dan tiga bulan ke depan. Tantangan dalam peramalan (out of sample forecast) data luas panen padi dengan menggunakan metode KSA adalah sangat terbatasnya data realisasi yang tersedia. Sejauh ini, jumlah titik data yang tersedia untuk peramalan hanya sebanyak 36 titik data yang mencakup periode Januari 2018 sampai dengan Desember 2020. Karena itu, kinerja peramalan dari motode ETS dievaluasi bukan hanya dengan melihat nilai MAPE, MAE, dan RMSE tapi juga perubahan selisih hasil peramalan terhadap realisasi seiring dengan bertambahnya titik data yang digunakan dalam peramalan. Hal ini memungkinkan untuk dilakukan dalam penelitian ini dengan menerapkan metode rolling window.

Plot data runtun waktu luas panen tanaman padi hasil pengamatan Survei KSA yang disajikan pada Gambar 1 memperlihatkan bahwa data luas panen padi tidak memiliki unsur tren tapi memiliki unsur musiman yang cenderung multiplikatif. Karena itu, model peramalan yang digunakan untuk memperkirakan luas panen satu, dua, dan tiga bulan ke depan harus memperhitungkan unsur musiman pada data. Terkait hal ini, model ETS merupakan alternatif model peramalan yang dapat digunakan karena memperhitungkan unsur musiman pada data, baik yang bersifat aditif maupun multiplikatif.

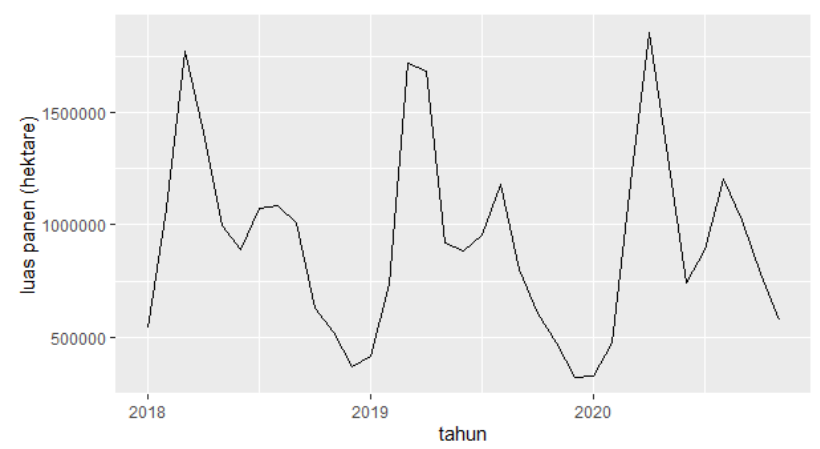

Gambar 1. Luas panen padi di Indonesia, Januari 2018-Desember 2020

Hasil peramalan (out of sample forecasts) luas panen padi untuk satu, dua, dan tiga bulan ke depan periode Januari 2020 sampai dengan Desember 2020 dengan menggunakan model ETS disajikan pada Tabel 4, 5, dan 6. Peramalan dilakukan dengan menggunakan metode rolling window sehingga spesifikasi model ETS bersifat dinamis seiring dengan penambahan data baru atau ekspansi jendela peramalan. Dapat dilihat bahwa selisih peramalan terhadap realisasi luas panen (kesalahan peramalan) cenderung semakin mengecil seiring dengan penambahan data training (training set). Dengan kata lain, semakin banyak titik data untuk peramalan, semakin baik akurasi hasil peramalan yang dihasilkan. Tabel 4, 5, dan 6 memperlihatkan bahwa akurasi peramalan luas panen padi untuk bulan Desember 2020 cukup baik, di mana selisih peramalan terhadap data realisasi untuk peramalan satu, dua, dan tiga bulan ke depan masing-masing sebesar 8,59 persen, 13,54 
persen, dan 8,59 persen. Selisih tersebut relatif lebih rendah untuk ramalan satu dan tiga bulan ke depan dibanding selisih perkiraan potensi panen dengan menggunakan luas fase generatif dan vegetatif awal pada periode yang sama.

Sebagai gambaran, sebagaimana tersaji pada Tabel 3, selisih perkiraan potensi panen untuk bulan Desember 2020 terhadap realisasi panen. Persentasi selisih dihitung dengan menghitung persentase perbedaan potensi luas panen terhadap realisasi panen. Selisih yang terjadi berdasarkan luas fase generatif pada bulan November 2020 (satu bulan ke depan), luas fase vegetatif akhir bulan Oktober 2020 (dua bulan ke depan), dan luas fase vegetatif awal bulan September 2020 (tiga bulan ke depan) hasil pengamatan Survei KSA masing-masing sebesar 39,47 persen, 7,50 persen, 48,35 persen. Hal ini mengindikasikan bahwa model ETS dapat dipertimbangkan untuk peramalan luas panen tanaman padi, khususnya di masa datang ketika implementasi Survei KSA sudah diterapkan setidaknya selama empat atau lima tahun. Kondisi ini berlaku untuk peramalan satu, dua, dan tiga bulan ke depan.

Tabel 4.2 Selisih perkiraan potensi luas panen Desember 2020 terhadap realisasi hasil KSA

\begin{tabular}{lccc}
$\begin{array}{c}\text { Dasar } \\
\text { perkiraan } \\
\text { potensi luas } \\
\text { panen }\end{array}$ & $\begin{array}{c}\text { Perkiraan } \\
\text { potensi } \\
\text { luas panen } \\
\text { (ha) }\end{array}$ & $\begin{array}{c}\text { Realisasi } \\
\text { luas panen } \\
\text { (ha) }\end{array}$ & $\begin{array}{c}\text { \% selisih } \\
\text { potensi } \\
\text { terhadap } \\
\text { realisasi }\end{array}$ \\
\hline $\begin{array}{l}\text { Luas fase } \\
\text { generatif }\end{array}$ & & & \\
November & 411.096 & 294.748 & 39,47 \\
$\begin{array}{l}\text { 2020 (1 bulan } \\
\text { ke depan) }\end{array}$ & & & \\
$\begin{array}{l}\text { Luas fase } \\
\text { vegetatif akhir }\end{array}$ & & & \\
$\begin{array}{l}\text { Oktober 2020 } \\
\text { (2 bulan ke }\end{array}$ & 316.840 & 294.748 & 7,50 \\
depan) & & & \\
Luas fase & & & \\
vegetatif awal & & & \\
September & 437.249 & 294.748 & \\
$\begin{array}{l}\text { 2020 (3 bulan } \\
\text { ke depan) }\end{array}$ & & & \\
\hline
\end{tabular}

Sumber: Data diolah

Selain itu, seiring dengan penambahan titik data untuk peramalan, terlihat bahwa spesifikasi model ETS yang sesuai dengan data luas panen padi hasil pengamatan Survei KSA adalah ETS (M,N,M), yakni model ETS yang mengakomodir galat multiplikatif, unsur musiman multiplikatif, dan tanpa unsur tren. Informasi yang tersaji pada Tabel 4.3, 4.4, dan 4.5 juga memperlihatkan bahwa hasil peramalan dengan metode ETS dapat merepresentasikan pola musiman pada data dengan sangat baik. Hal ini merupakan sesuatu yang sangat penting dalam permalan luas panen padi bulanan yang memiliki unsur musiman seperti data luas panen padi bulanan.

Persentase selisih peramalan terhadap data realisasi sendiri sangat beragam setiap bulannya. Nilai persentase selisih positif menunjukkan bahwa hasil peramalan cenderung memprediksi luas panen lebih tinggi dibandingkan dengan realisasi panen. Sebaliknya, nilai persentase selisih negatif mengindikasikan bahwa ramalan luas panen cenderung lebih rendah dibandingkan realisasi panen.

Tabel 4.3 Hasil peramalan luas panen padi satu bulan ke depan dengan model ETS

\begin{tabular}{lccrc}
\hline $\begin{array}{c}\text { Periode } \\
\text { waktu }\end{array}$ & $\begin{array}{c}\text { Realisasi } \\
\text { luas panen } \\
\text { (ha) }\end{array}$ & $\begin{array}{c}\text { Ramalan } \\
\text { luas panen } \\
\text { satu bulan } \\
\text { ke depan } \\
\text { (ha) }\end{array}$ & $\begin{array}{c}\text { \% selisih } \\
\text { peramalan } \\
\text { terhadap } \\
\text { data } \\
\text { realisasi }\end{array}$ & $\begin{array}{c}\text { Spesifik } \\
\text { asi } \\
\text { model } \\
\text { ETS }\end{array}$ \\
\hline Januari & 324.355 & 320.075 & $-1,32$ & A,N,N \\
Februari & 474.600 & 324.354 & $-31,66$ & A,N,N \\
Maret & 1.187 .680 & 474.585 & $-60,04$ & A,N,N \\
April & 1.855 .764 & 1.049 .462 & $-43,45$ & M,N,M \\
Mei & 1.303 .167 & 861.273 & $-33,91$ & M,N,M \\
Juni & 743.591 & 882.135 & 18,63 & M,N,M \\
Juli & 892.228 & 967.951 & 8,49 & M,N,M \\
Agustus & 1.204 .010 & 1.063 .013 & $-11,71$ & M,N,M \\
September & 1.021 .683 & 794.907 & $-22,20$ & M,N,M \\
Oktober & 780.887 & 602.526 & $-22,84$ & M,N,M \\
November & 574.563 & 481.479 & $-16,20$ & M,N,M \\
Desember & $\mathbf{2 9 4 . 7 4 8}$ & $\mathbf{3 2 0 . 0 5 9}$ & $\mathbf{8 , 5 9}$ & M,N,M \\
\hline Sumber: Data diolah & & &
\end{tabular}


Tabel 4.4 Hasil peramalan luas panen padi dua bulan ke depan dengan model ETS

\begin{tabular}{lrrrr}
\hline $\begin{array}{c}\text { Periode } \\
\text { waktu }\end{array}$ & $\begin{array}{c}\text { Realisasi } \\
\text { luas panen } \\
\text { (ha) }\end{array}$ & $\begin{array}{c}\text { Ramalan } \\
\text { luas panen } \\
\text { dua bulan } \\
\text { ke depan } \\
\text { (ha) }\end{array}$ & $\begin{array}{c}\text { \% selisih } \\
\text { peramalan } \\
\text { terhadap } \\
\text { data } \\
\text { realisasi }\end{array}$ & $\begin{array}{c}\text { Spesifik } \\
\text { asi } \\
\text { model } \\
\text { ETS }\end{array}$ \\
\hline Januari & 324.355 & - & - & - \\
Februari & 474.600 & 320.075 & $-32,56$ & A,N,N \\
Maret & 1.187 .680 & 324.354 & $-72,69$ & A,N,N \\
April & 1.855 .764 & 474.585 & $-74,43$ & A,N,N \\
Mei & 1.303 .167 & 678.489 & $-47,94$ & M,N,M \\
Juni & 743.591 & 828.405 & 11,41 & M,N,M \\
Juli & 892.228 & 953.849 & 6,91 & M,N,M \\
Agustus & 1.204 .010 & 1.175 .748 & $-2,35$ & M,N,M \\
September & 1.021 .683 & 858.012 & $-16,02$ & M,N,M \\
Oktober & 780.887 & 600.310 & $-23,12$ & M,N,M \\
November & 574.563 & 472.828 & $-17,71$ & M,N,M \\
Desember & $\mathbf{2 9 4 . 7 4 8}$ & $\mathbf{3 3 4 . 6 6 0}$ & $\mathbf{1 3 , 5 4}$ & M,N,M \\
\hline Suln
\end{tabular}

Sumber: Data diolah

Terkait akurasi peramalan, hasil perhitungan ukuran akurasi yang disajikan pada Tabel 4.6 memperlihatkan bahwa nilai MAPE untuk peramalan satu bulan ke depan sebesar 25,25 persen, dua bulan ke depan sebesar 28,97 persen, dan tiga bulan ke depan sebesar 32,13 persen. Ramalan panen menggunakan metode ETS memiliki nilai MAPE, MAE, dan RMSE yang relatif lebih tinggi dibandingkan dengan ukuran akurasi prediksi panen berdasarkan hasil amatan KSA seperti yang tersaji pada Tabel 1. Meskipun begitu, nilai MAPE masih berada dalam rentang 20 hingga 50 persen, menunjukkan bahwa penggunaan metode ETS menghasilkan prediksi panen yang masih wajar (reasonable forecasting).

Tabel 4.5 Hasil peramalan luas panen padi tiga bulan ke depan dengan model ETS

\begin{tabular}{lrrrr}
\hline $\begin{array}{c}\text { Periode } \\
\text { waktu }\end{array}$ & $\begin{array}{c}\text { Realisasi } \\
\text { luas panen } \\
\text { (ha) }\end{array}$ & $\begin{array}{c}\text { Ramalan } \\
\text { luas panen } \\
\text { tiga bulan } \\
\text { ke depan } \\
\text { (ha) }\end{array}$ & $\begin{array}{c}\text { \% selisih } \\
\text { peramalan } \\
\text { terhadap } \\
\text { data } \\
\text { realisasi }\end{array}$ & $\begin{array}{c}\text { Spesifik } \\
\text { asi } \\
\text { model } \\
\text { ETS }\end{array}$ \\
\hline Januari & 324.355 & - & - & - \\
Februari & 474.600 & - & - & - \\
Maret & 1.187 .680 & 320.075 & $-73,05$ & A,N,N \\
April & 1.855 .764 & 324.354 & $-82,52$ & A,N,N \\
Mei & 1.303 .167 & 474.585 & $-63,58$ & A,N,N \\
Juni & 743.591 & 641.690 & $-13,70$ & M,N,M \\
Juli & 892.228 & 901.804 & 1,07 & M,N,M \\
Agustus & 1.204 .010 & 901.804 & $-25,10$ & M,N,M \\
September & 1.021 .683 & 895.105 & $-12,39$ & M,N,M \\
Oktober & 780.887 & 598.417 & $-23,37$ & M,N,M \\
November & 574.563 & 471.323 & $-17,97$ & M,N,M \\
Desember & $\mathbf{2 9 4 . 7 4 8}$ & $\mathbf{3 2 0 . 0 5 3}$ & $\mathbf{8 , 5 9}$ & M,N,M \\
\hline
\end{tabular}

Sumber: Data diolah

Tabel 4.6 Akurasi peramalan (out of sample forecasts) luas panen padi Januari-Desember 2020 dengan metode ETS

\begin{tabular}{cccc}
$\begin{array}{c}\text { Ukuran } \\
\text { Akurasi }\end{array}$ & $\begin{array}{c}\text { Ramalan } \\
\text { satu bulan } \\
\text { ke depan }\end{array}$ & $\begin{array}{c}\text { Ramalan } \\
\text { dua bulan } \\
\text { ke depan }\end{array}$ & $\begin{array}{c}\text { Ramalan } \\
\text { tiga bulan } \\
\text { ke depan }\end{array}$ \\
\hline $\begin{array}{c}\text { MAPE (\%) } \\
\text { MAE (ribu } \\
\text { hektar) }\end{array}$ & 25,25 & 28,97 & 32,13 \\
$\begin{array}{c}\text { RMSE } \\
\text { (ribu } \\
\text { hektar) }\end{array}$ & 355,18 & 334,94 & 407,89 \\
\hline
\end{tabular}

Sumber: Data diolah

Salah satu penyebab relatif tingginya nilai MAPE adalah ukuran training set yang relatif kecil, yakni hanya 24 sampai dengan 35 titik data untuk peramalan satu bulan ke depan, 24 sampai dengan 34 titik data untuk peramalan dua bulan ke depan, dan 24 sampai dengan 33 titik data untuk peramalan tiga bulan ke depan. Pola penurunan kesalahan peramalan seiring dengan penambahan training set seperti yang tersaji pada Tabel 4.3, 4.4, dan 4.5 mengindikasikan bahwa nilai MAPE, yang merupakan fungsi dari kesalahan peramalan, akan semakin kecil seiring dengan penambahan data realisasi pengamatan hasil KSA di masa datang. Hal ini ditunjukkan dengan cenderung semakin mengecilnya selisih nilai peramalan terhadap realisasi seiring dengan penambahan data untuk peramalan. Persentase selisih nilai peramalan terhadap data realisasi hasil Survei KSA untuk bulan Desember sebesar 8,59 persen untuk ramalan satu bulan ke depan, 13,54 persen untuk ramalan dua bulan ke depan, dan 8,59 persen untuk tiga bulan ke depan. Dengan kata lain, akurasi hasil peramalan dengan metode ETS akan semakin baik seiring dengan penambahan data realisasi pengamatan hasil KSA. Dengan demikian, model ETS dapat dipertimbangkan sebagai alternatif dalam peramalan luas panen padi di Indonesia.

\section{KESIMPULAN}

Perkiraan luas panen padi satu bulan ke depan dengan menggunakan luas tanaman padi fase generatif pada bulan berjalan memiliki tingkat akurasi yang relatif tinggi. Hal ini ditunjukkan oleh nilai MAPE yang relatif kecil 
yakni sebesar 7,52 persen, atau dengan kata lain prediksi yang dilakukan termasuk dalam kategori highly accurate. Rata-rata absolut perbedaan perkiraan potensi panen satu bulan ke depan dengan realisasi estimasi luas panen hasil pengamatan KSA sebesar 60,76 ribu hektar. Sementara itu, perkiraan potensi panen dua dan tiga bulan ke depan dengan menggunakan luas tanaman padi fase vegetatif akhir dan vegetatif awal memiliki nilai MAPE yang relatif besar, yakni masing-masing sebesar 18,94 persen dan 15,04 persen. Hal ini memperlihatkan bahwa untuk peramalan luas panen padi dua dan tiga bulan ke depan diperlukan alternatif model peramalan yang dapat memberikan akurasi yang lebih baik dengan nilai MAPE yang lebih kecil.

Hasil peramalan (out of sample forecasts) luas panen padi satu, dua, dan tiga bulan ke depan untuk periode Januari 2020 sampai dengan Desember 2020 dengan menggunakan model ETS dan metode rolling window menghasilkan nilai akurasi yang lebih rendah dibandingkan dengan prediksi panen berdasarkan potensi KSA. Namun, selisih peramalan terhadap realisasi luas panen (kesalahan peramalan) cenderung semakin mengecil seiring dengan penambahan data training (training set). Hal ini mengindikasikan semakin banyak titik data untuk peramalan, semakin baik akurasi hasil peramalan yang dihasilkan. Kondisi ini berlaku untuk peramalan satu, dua, dan tiga bulan ke depan. Selain itu, untuk peramalan luas panen padi pada Desember 2020, model ETS cenderung memberikan perkiraan yang lebih mendekati data realisasi dibanding perkiraan potensi panen berdasarkan hasil KSA. Model ETS dapat dipertimbangkan sebagai alternatif dalam peramalan luas panen padi dengan menggunakan data hasil Survei KSA. Selain itu, seiring dengan penambahan titik data untuk peramalan, terlihat bahwa bahwa spesifikasi model ETS yang sesuai dengan data luas panen padi hasil pengamatan Survei KSA adalah ETS (M,N,M), yakni model ETS yang mengakomodir kesalahan multiplikatif, unsur musiman multiplikatif, dan tanpa unsur tren.

\section{DAFTAR PUSTAKA}

[1] Peter Rosner, L., \& McCulloch, N. 2008. A note on rice production, consumption and import data in Indonesia. Bulletin of Indonesian Economic Studies, 44(1), 81-92.

[2] Ruslan, K. 2019. Improving Indonesia's Food Statistics through the Area Sampling Frame Method. Center for Indonesian Policy Studies. doi: 10.35497/287781

[3] Hyndman, R. J., A. B. Koehler, R. D. Snyder and S. Grose. 2002. A state space framework for automatic forecasting using exponential smoothing methods, International Journal of Forecasting, 18(3), 439-454.

[4] Mubekti \& Sumargana, L. 2016. Pendekatan Kerangka Sampel Area untuk Estimasi dan Peramalan Produksi Padi. Jurnal PANGAN, 25 (2), $71-82$.

[5] Wigton, W.H., \& Bormann, P. 1978. Guide to area sampling frame construction utilizing satellite imagery. Second International Training Course in Remote Sensing Applications for Agriculture: Crop Statistics and Agricultural Census, 25 April-13 May 1977, Rome.

[6] Muhlis. 2018. Area Sampling Frame: A New Approach to Reform Agricultural Data Collection. Asia-Pacific Economic Statistics Week. 2018. Tersedia dari : https://communities.unescap.org/asiapacific-economic-statistics/apes-2018featured-papers.

[7] Pan Y, Wang M, Wei G, Wei F, Shi K, Li L, Sun G. 2010. Application of Area-frame sampling for agricultural statistics in China. In Proceedings of the Fifth International Conference on Agricultural Statistics (ICASV). Rome: FAO. Teresedia dari: fao.org.

[8] Durante AC, Lapitan P, Megill D, Rao LN. 2018. Improving Paddy Rice Statistics Using Area Sampling Frame Technique. Asian Development Bank Economics Working Paper Series. 2018 Nov 28: 565. doi: 10.22617/WPS189643-2.

[9] Prasetyo, Octavia Rizky, Kadir, and Amalia, Ratna Rizki. 2020. A Pilot Project of Area 
Sampling Frame for Maize Statistics: Indonesia's Experience, 36(4): 997 - 1006.

[10] Gallego, FJ. 2015. Area Sampling Frames for Agricultural and Environmental Statistics. EUR 27595 EN. doi: 10.2788/88253.

[11] Gallego, F.J. 1995. Sampling Frames of Square Segments. ReportEURI631EN.1. Joint Research Centre, European Commission, Luxembourg

[12] Badan Pusat Statistik (BPS). 2018. Pedoman Teknis Pendataan Statistik Pertanian Tanaman Pangan Terintegrasi dengan Metode Kerangka Sampel Area (KSA) 2018. Jakarta: Badan Pusat Statistik.

[13] Hyndman \& Athanasopoulos. 2018. Forecasting: Principles and Practices (2nd Edition). OTexts.org/fpp2/

[14] Hyndman, R. J., \& Koehler, A. B. 2006. Another look at measures of forecast accuracy. International journal of forecasting, 22 (4), 679-688.

[15] Ord, J. K., Koehler, A. B. \& Snyder, R. D. 1997. 'Estimation and prediction for a class of dynamic nonlinear statistical models', Journal of the American Statistical Association 92, 1621- 1629.

[16] Jofipasi et al. 2017. Selection for the best ETS (error, trend, seasonal) model to forecast weather in the Aceh Besar District. IOP Conf. Series: Materials Science and $\begin{array}{llll}\text { Engineering } & \mathbf{3 5 2} & \text { (2018) } & 012055\end{array}$ doi:10.1088/1757-899X/352/1/012055

[17] Shamshad et al. 2019. Modeling and Forecasting Weather Parameters using ANN-MLP, ARIMA and ETS model: A case study for Lahore, Pakistan. International Journal of Scientific \& Engineering Research. 10(4): 351 ISSN 2229-5518

[18] Ke, G., Hu, Y., Huang, X., Peng, X., Lei, M., Huang, C., Gu, L., Xian, P., \& Yang, D. 2016. Epidemiological analysis of hemorrhagic fever with renal syndrome in China with the seasonal-trend decomposition method and the exponential smoothing model.Scientific reports, $6, \quad 39350$. https://doi.org/10.1038/srep39350

[19] Zhanao Sun. 2020. Comparison of Trend Forecast Using ARIMA and ETS Models for S\&P500 Close Price. ICEBI 2020: 2020 The 4th International Conference on E-Business and Internet October 2020 Pages 57-60 https://doi.org/10.1145/3436209.3436894

[20] Hyndman, R. J., \& Khandakar, Y. 2008. Automatic time series forecasting: the forecast package for R. Journal of Statistical Software, 27 http://www.jstatsoft.org/v27/i03

[21] Er. Garima Jain, Bhawna Mallick,A Study of Time Series Models ARIMA and ETS", International Journal of Modern Education and Computer Science (IJMECS). 9(4): pp.57-63, 2017.2 DOI: 10.5815/ijmecs.2017.04.07

[22] Bowerman, B.L. and O'Connell, R.T. (1993, 2004). Forecasting and Time Series: An Applied Approach,. 3 and 4 edition, Duxbury Press: USA.

[23] Lewis, C. D. 1982. Industrial and business forecasting methods: A practical guide to exponential smoothing and curve fitting. Butterworth-Heinemann.

[24] Zivot, E., \& Wang, J. 2006. Time Series Concepts. Modeling Financial Time Series with S-PLUS®, 57-110. 